\title{
The Effect of Alterations in Water Quality Parameters on the Occurrence of Bacterial Diseases in Different Aquatic Environments
}

\section{Hanan S. Khalefa ${ }^{1 *}$, Dalia A. Abdel-Moneam² ${ }^{2}$ Elshaimaa Ismael ${ }^{1}$, Mahmoud Mostafa Fathy $^{2}$ WaZiry ${ }^{3}$, Mennaallah Samir Gaber Ali ${ }^{3}$, Manal M. Zaki ${ }^{1}$}

${ }^{1}$ Department of Veterinary Hygiene and Management, Faculty of Veterinary Medicine, Cairo University, Giza 12211, Egypt; ${ }^{2}$ Department of Aquatic Animal Medicine and Management, Faculty of Veterinary Medicine, Cairo University; Giza 12211, Egypt; ${ }^{3}$ Faculty of science and Biotechnology, MSA University, 6th October City 12573, Egypt.

\begin{abstract}
The current study investigated the influence of adverse water quality parameters in different localities (Qarun Lake, Fayoum Province, Egypt; Mariotteya stream, Giza Governorate, Egypt; and Mediterranean coastal water, Alexandria Governorate, Egypt) on different fish species during the winter. Water and fish samples were collected to evaluate the physicochemical properties and heavy metal distribution in the water. Furthermore, bacteriological analysis of water and fish was performed. The physicochemical characteristics of water samples revealed high conductivity, alkalinity, and higher values of water hardness in Lake Qarun, Fayoum province and Mediterranean coastal water, Alexandria Governorate. However, the parameters in Mariotteya water were within normal limits. Heavy metals were detected in Lake Qarun and the Mediterranean Coast. However, none of the heavy metals analyzed were found in the Mariotteya water samples. Moreover, detected trace elements, cadmium and lead, exceeded the permissible limits. The bacterial load of the collected water samples revealed only the isolation of Escherichia coli and other coliform bacteria from Lake Qarun, while other bacteria included Vibrio spp. $\left(2.48 \log _{10} \mathrm{CFU} / \mathrm{mL}\right)$, Aeromonas spp. $\left(2.70 \log _{10}\right.$ $\mathrm{CFU} / \mathrm{mL})$, and Pseudomonas spp. $\left(3.18,2.04 \log _{10} \mathrm{CFU} / \mathrm{mL}\right)$ isolated from Lake Qarun and Mariotteya stream, and Staphylococcus spp. $\left(2.00,1.95\right.$, and $\left.1.00 \log _{10} \mathrm{CFU} / \mathrm{mL}\right)$ from Mariotteya stream, Lake Qarun, and Mediterranean Coast, respectively. Among the isolated bacteria from collected fishes, Aeromonas spp. weres detectable at a higher percentage (36.2\%) followed by Vibrio spp. (31.4\%), Pseudomonas spp. (16.2\%), and Staphylococcus spp. (6.7\%). Moreover, the highest percentage of bacterial isolates was recovered from Lake Qarun. Large shrimps from the Mediterranean Coast showed a high percentage of Vibrio spp. (40\%) isolation. The log of viable microbial count and chemical parameters in water bodies had a strong correlation coefficient $(r>0.75)$, suggesting that the ecosystem is highly polluted by agricultural and industrial contamination.
\end{abstract}

Keywords | Aquatic environment, Water quality, Heavy metals, Bacterial contamination

Received | June 03, 2021; Accepted | August 30, 2021; Published | November 01, 2021

*Correspondence | Hanan Saad Khalefa, Department of Veterinary Hygiene and Management, Faculty of Veterinary Medicine, Cairo University, Giza 12211, Egypt; Email: hanansaad04@gmail.com

Citation | Khalefa HS, Abdel-Moneam DA, Ismael E, Waziry MFF, Ali MSG, Zaki MM (2021). The effect of alterations in water quality parameters on the occurrence of bacterial diseases in different aquatic environments. Adv. Anim. Vet. Sci. 9(12): 2084-2094.

DOI | http://dx.doi.org/10.17582/journal.aavs/2021/9.12.2084.2094

ISSN (Online) | 2307-8316; ISSN (Print) | 2309-3331

Copyright (c) 2021 Khalefa et al. This is an open access article distributed under the Creative Commons Attribution License, which permits unrestricted use, distribution, and reproduction in any medium, provided the original work is properly cited.

\section{INTRODUCTION}

$\mathrm{E}$ gypt is a leading African country in the aquaculture industry, accounting for around 1.8 million tons of total production. Fish aquaculture in Egypt has rapidly increased from 1.45 million tons in 2013 to about 1.82 million tons in 2017 , with a $25 \%$ total increase (Ali et al ., 2020 ) as a result of the rapid expansion in the application of new technologies and improved rearing and managemental strategies (Kaleem and Sabi, 2020). 
Fish is a good source of low-cost and high-nutrient protein sources. Thus, the Egyptian government paid particular attention to fish meat as part of its food security policy (Elsayed et al., 2018). According to Saeed and Shaker (2008), Egyptian marine life suffers from poor water quality because water is polluted by sewage disposal and agrochemicals and exposure to high environmental influences leading to an outbreak of bacterial infection among fish. The pollution of the aquatic ecosystem by natural and inorganic chemicals is one of the most significant risks to marine life because polluted water stresses farmed fish and makes them susceptible to infectious diseases, leading to high mortality (Sarmento et al., 2004). Fish feed and live in marine ecosystems and cannot avoid the adverse effects of pollutants (Yarsan and Yipel, 2013).

Water quality, controlled by the physical, chemical, and biological properties of water, is a very sensitive problem in the aquatic environment (Sargaonkar and Deshpande, 2003; Diersing, 2009; Simpi et al., 2011). Microbiological and chemical pollutants may cause lakes' water quality to deteriorate. The marine ecosystem is exposed to a variety of pollutants with the incorporation of industrial, agricultural, and domestic wastewater.

Heavy metal contamination in the marine ecosystem has become a major health issue in recent years, it act as essential indicator of hygienic status of water, as heavy metal concentrations reflect the pollution status of those areas (Younis et al., 2020), because certain metals are not biodegradable and accumulate in various organs of animals and humans. Thus, determining trace metal concentrations in natural water systems has gained attention to monitor environmental pollution (Saad et al., 2012; Dhanakumar et al., 2015). Moreover, this accumulation is dependent on Heavy metals intake, storage, and removal from the body (Abdallah and Morsy, 2013). Lead, arsenic, and cadmium are the most hazardous metals to humans, posing significant health risks (Abd El-Hady, 2007).

Stress caused by unfavorable environmental factors leads to reduced fish immunity and paves the way to pathogens and parasites (Eissa, 2002). The members of the Enterobacteriaceae family are commonly found among the most common bacteria on freshwater fish. The coliform group and Escherichia coli are very important among the bacterial indicators used to define water quality and health risk (Giannoulis et al., 2005). Coliform bacteria have long been used to suggest fecal water contamination and, therefore, a health risk. Bacterial pathogens are a major threat to global fish production because of the high economic value of the diseases they cause (Wamala et al., 2018). Many previous studies have identified Aeromonas, Edwardsiella tarda, Flavobacterium columnare, Yersinia ruckeri, Staphylococcus, Vibrio vulnificus, Streptococcus agalactiae, and Pseudomonas species because they are among the most economically significant bacterial fish pathogens (Falaise et al., 2016; Zhang et al., 2018; Yaseen et al., 2020). Finally, fish in aquariums with good water quality can live longer and live healthier than fish in the wild.

Consequently, the current study aimed to assess the water quality by measuring physicochemical parameters in different surface water areas as well as determine the risk of microorganisms in the water and cultured species.

\section{MATERIALS AND METHODS}

\section{STUdy AREA}

Water and fish samples were obtained during the winter between (November 2019 and January 2020) from three sites in Egypt: Shakshouk area, Lake Qarun at Fayoum Governorate, Mariotteya drain at Giza Governorate; a 4-km distance that ranges from Shabramant to Abouseer city, and Mediterranean Coast at Alexandria Governorate as shown in Figure 1.

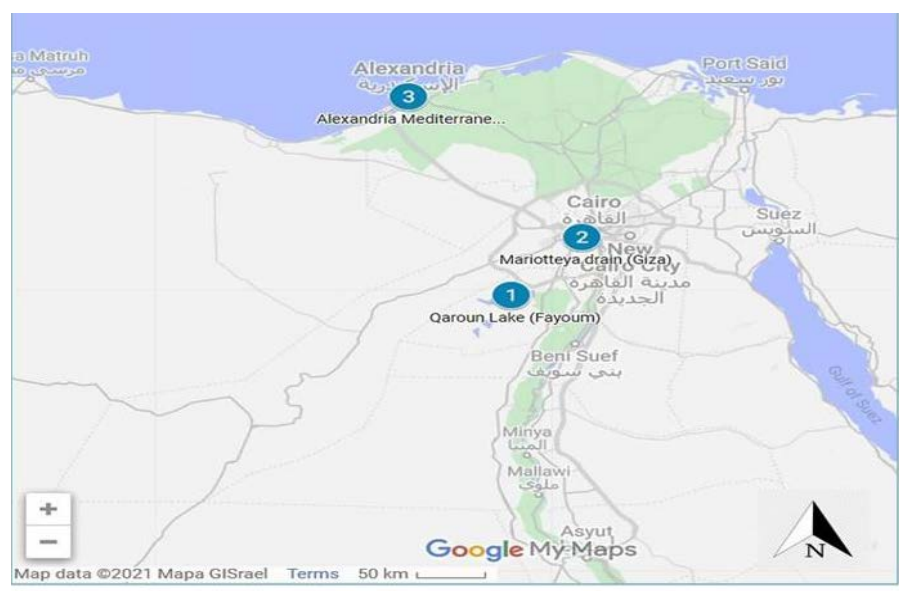

Figure 1: A map showing the studied areas: (1) Qaroun Lake at Fayoum governorate; (2) Mariotteya drain at Giza governorate; (3) Mediterranean coast at Alexandria governorate. The map was made using Google my Maps application.

\section{SAMPLING}

\section{WATER SAMPLES}

Water samples were collected from each of the three study areas (Figure 1). In addition, water samples were taken 30 $\mathrm{cm}$ below the surface of the stream in the middle of the stream. Water samples were collected in sterile $500-\mathrm{mL}$ glass and 2-L bottled for bacteriological and physiochemical analysis, respectively. The samples were carefully labeled before being shipped to the testing laboratory in an icebox surrounded by ice gel packs.

\section{FISH SAMPLES}

Collected from the Shakshouk area, Lake Qarun, Fayoum were 30 Oreochromis niloticus fish (Nile Tilapia), five Tilapia 
zilli, and 50 small artemia shrimps. Sample collection follows APHA (1970), and three to five shrimp samples were pooled and homogenized using $10-\mathrm{mL}$ sterile alkaline peptone water and stomacher. Also, five O. niloticus were collected from the Mariotteya drain, Giza. Fifteen large shrimps were collected along the Mediterranean Sea's coast of Alexandria. Fish samples were held fresh and transported to the laboratory for bacteriological testing.

\section{WATER ANALYSIS}

PhysicAl AND CHEMiCAL ANALYSis OF WATER SAMPLES

Standard methods for examining water and wastewater were used to analyze the physical and chemical parameters (APHA, 2005). An electrometric $\mathrm{pH}$ meter $\left(\mathrm{pHep}^{\circledR} \mathrm{HI}\right.$ 98107, Milan, Italy) was used to determine the $\mathrm{pH}$ of the water samples. A conductivity meter was used to calculate electrical conductivity (EC) at $25^{\circ} \mathrm{C}$. The carbonate $\left(\mathrm{CO}_{3}{ }^{2-}\right)$ and bicarbonate $\left(\mathrm{HCO}_{3}{ }^{-}\right)$ions were measured titrimetrically against $0.1 \mathrm{~N} \mathrm{HCl}$. Ion chromatography (IC; DX5000 Dionex System, Dionex Corp., Sunnyvale, CA, USA) was used to calculate major anions such as chloride $\left(\mathrm{Cl}^{-}\right)$, sulfate $\left(\mathrm{SO}_{4}{ }^{2-}\right)$, and phosphate $\left(\mathrm{PO}_{4}{ }^{3-}\right)$. Inductively coupled plasma-optical emission spectrometry was used to calculate major cations such as calcium $\left(\mathrm{Ca}^{2+}\right)$, potassium $\left(\mathrm{K}^{+}\right)$, magnesium $\left(\mathrm{Mg}^{2+}\right)$, and sodium $\left(\mathrm{Na}^{+}\right)$.

\section{HEAVY METAL DETERMinATION}

Water samples were analyzed for the presence of lead $(\mathrm{Pb})$, zinc $(\mathrm{Zn})$, copper $(\mathrm{Cu})$, and cadmium $(\mathrm{Cd})$. Nitric acid (analytical grade) was applied on collected water samples until the $\mathrm{pH}$ was $<2$. The Thermo Science iCAP 6500 ICO-OES (Thermo Fisher Scientific, Waltman, MA, USA) and the US EPA Process 2007 were used to calculate element concentrations and measured in parts per billion (in milligram per liter). The atom elements were excited with argon gas, and the blank values for each element were determined using the sample values. These tests were conducted at 'the Central Laboratory of the Faculty of Agriculture, Cairo University, Cairo, Egypt.

\section{Microbiological EXAMinATIONS OF WATER SAMPLES}

Water samples were microbiologically tested 'following the guidelines of APHA (1998) guidelines. Total and fecal coliform were counted as the most probable numbers (MPN/100 mL water) using the multipletube fermentation technique with Lauryl Tryptose Broth (Biolife, Milan, Italy) for standard presumptive examination. The MPN confirmation process was carried out by moving positive presumptive tubes (gas production within 24-48 h) to $2 \%$ Brilliant green bile lactose broth (Difco, Thermo Fisher Scientific) and checking for gas production within $48 \mathrm{~h}$ at $35^{\circ} \mathrm{C}$ and $44.5^{\circ} \mathrm{C}$ for total and fecal coliforms, respectively. The poured plate method was used to determine the total bacterial count (TBC) of water samples. After making serial dilutions of water samples, 1 $\mathrm{mL}$ was transferred in triplicates into a sterile glass Petri dish. Each plate received approximately $15 \mathrm{~mL}$ of melted nutrient agar medium then mixed and left to solidify. The plates were incubated for $72 \mathrm{~h}$ at $37^{\circ} \mathrm{C}$. Following the incubation time, the number of produced colonies per plate of the same dilution was counted, and the mean value was determined. The mean $\left(\log _{10}\right)$ of the results was given (Ronald, 2010). To isolate and maintain certain pathogenic bacteria, $1 \mathrm{~mL}$ of each of the last three dilutions of water samples was transferred into Petri dishes, along with approximately $15.0 \mathrm{~mL}$ of a particular culture media (Staphylococcus 110 medium, Aeromonas selective agar medium, thiosulfate citrate bile salt agar, TCBS (Oxoid, Thermo Fisher Scientific), and Pseudomonas agar medium) and hardened. Petri dishes were placed upside down in an incubator at $37^{\circ} \mathrm{C}$ for $72 \mathrm{~h}$.

\section{BACTERIOLOGICAL EXAMINATION OF FISH SAMPLES}

The collected fish samples were externally sterilized with $70 \%$ ethanol (APHA, 2012). Consequently, aseptic swabs of skin, kidney, and liver were inoculated in nutrient broth then streaked on tryptic soy agar (TSA) Staphylococcus 110 media, Aeromonas selective agar medium, Pseudomonas agar medium, and TCBS (Oxiod, Thermo Fisher Scientific). Both inoculated plates and broth were incubated at $29^{\circ} \mathrm{C}$ overnight and $35 \pm 2^{\circ} \mathrm{C}$ for 3 days under aerobic conditions. Following the incubation cycle, a single colony from each suspected isolate was picked up and restreaked on a new plate of its perused original culture media before being reincubated under similar conditions. A loopful of each pure culture was streaked onto slanted trypticase soy agar supplemented with $2 \% \mathrm{NaCl}$ to serve as a stock for biochemical identification. Moreover, TSA slant and BHI broth with $15 \%$ glycerol were used to preserve the isolates for further inspection (Mahmoud et al., 2021).

\section{BACTERIA IDENTIFICATION}

The pure isolates were identified using colonial morphology, Gram staining for microscopical analysis, and descriptions of the form and arrangement of bacteria (Beveridge, 2001). The isolates were then biochemically classified using indole, Kovac's reagent, Simmon's citrate agar, MR, VP tests, triple sugar iron (Lab M Ltd., Lancashire, UK), and $\mathrm{H}_{2} \mathrm{~S}$ development for identification to genus or species level (A1-Harbi and Uddin, 2005). In parallel, the commercial API 20E strips were also used.

\section{STATISTICAL ANALYSIS}

The relationships between physico-chemical water quality variables, as well as, the microbiological loads, were evaluated using bivariate Pearson correlation coefficients $(r)$. The correlation between bacterial isolation rates and different sites was tested using the chi-square test for 
OPEN OACCESS

independence $\left(\chi^{2}\right)$ and Fisher's exact test (FET). Statistics were considered significant when the $p$ value was $<0.05$. The PASW Statistics (SPSS, Chicago, IL, USA), version 18.0, was used for analysis.

\section{RESULTS}

\section{Physicochemical WATER EXAMination}

The physicochemical water analysis of the collected samples from three sites (Table 1) showed that the $\mathrm{pH}$ value ranged from 7.36 to 7.87. Electrical conductivity is a measurement of the water's ability to transmit electric current as well as a method for determining water purity. The Alexandria Mediterranean Coast and Lake Qarun all had electrical conductivity in the range of $38.2-39.6 \mathrm{ds} / \mathrm{m}$, while Mariotteya stream water only had $2.11 \mathrm{ds} / \mathrm{m}$. The results of the current study illustrated that the mean concentrations of major anions $\left(\mathrm{CO}_{3}^{-2}, \mathrm{HCO}^{-}, \mathrm{Cl}^{-}\right.$, and $\left.\mathrm{SO}_{4}^{-2}\right)$ and major cations $\left(\mathrm{Na}^{+}, \mathrm{K}^{+}, \mathrm{Ca}^{2+}\right.$, and $\left.\mathrm{Mg}^{2+}\right)$ were highest in the Mediterranean Coast Alexandria, Lake Qarun, and Mariotteya stream.

Table 1: Physicochemical parameters of different surface water samples collected in winter 2019, Egypt.

\begin{tabular}{|c|c|c|c|c|c|}
\hline \multirow[t]{2}{*}{ Parameters } & \multirow[t]{2}{*}{ Units } & \multicolumn{3}{|r|}{ Sites } & \multirow[t]{2}{*}{ Guideline FAO, 1994} \\
\hline & & $\begin{array}{l}\text { Mariotteya } \\
\text { stream (Giza) }\end{array}$ & $\begin{array}{l}\text { Lake Qarun } \\
\text { (Fayoum) }\end{array}$ & Mediterranean coast (Alexandria) & \\
\hline $\mathrm{pH}$ & & 7.36 & 7.87 & 7.82 & $6.50-9.00^{\mathrm{a}}$ \\
\hline $\mathrm{EC}$ & $\mathrm{ds} / \mathrm{m}$ & 2.11 & 39.6 & 38.2 & - \\
\hline $\mathrm{CO}_{3}$ & $\mathrm{mg} / \mathrm{L}$ & 0.00 & 1.20 & 0.00 & - \\
\hline $\mathrm{HCO}_{3}$ & $\mathrm{mg} / \mathrm{L}$ & 4.40 & 5.80 & 11.00 & - \\
\hline Chloride & $\mathrm{mg} / \mathrm{L}$ & 15.00 & 400.00 & 832.00 & $120.00^{a}$ \\
\hline $\mathrm{SO}_{4}^{2-}$ & $\mathrm{mg} / \mathrm{L}$ & 20.48 & 263.31 & 132.09 & 960.00 \\
\hline $\mathrm{Ca}^{2+}$ & $\mathrm{mg} / \mathrm{L}$ & 6.33 & 33.33 & 20.00 & 400.00 \\
\hline $\mathrm{Mg}^{2+}$ & $\mathrm{mg} / \mathrm{L}$ & 6.00 & 90.33 & 153.00 & 60.00 \\
\hline $\mathrm{K}^{+}$ & $\mathrm{mg} / \mathrm{L}$ & 0.44 & 11.65 & 38.18 & 2.00 \\
\hline $\mathrm{Na}^{+}$ & $\mathrm{mg} / \mathrm{L}$ & 27.11 & 534.99 & 763.91 & 919.00 \\
\hline Phosphate & $\mathrm{mg} / \mathrm{L}$ & 2.19 & 2.54 & 2.74 & 2.00 \\
\hline
\end{tabular}

${ }^{2}$ Guideline (CCME, 2007). EC: electric conductance, $\mathrm{CO}_{3}$ : carbonate, $\mathrm{HCO}_{3}$ : bicarbonate, $\mathrm{Cl}$ : chloride, $\mathrm{SO}_{4}$ : sulfate, $\mathrm{Na}$ : sodium, $\mathrm{K}$ : potassium, $M g$ : magnesium, $C a$ : calcium.

Table 2: Correlations matrix of the analyzed chemical parameters in the examined water samples.

\begin{tabular}{|c|c|c|c|c|c|c|c|c|c|c|c|c|}
\hline & & pH & EC & $\mathrm{CO}_{3}$ & $\mathrm{HCO}_{3}$ & $\mathrm{Cl}^{-}$ & $\mathrm{SO}_{4}{ }^{2-}$ & $\mathrm{Ca}^{2+}$ & $\mathrm{Mg}^{2+}$ & $\mathbf{K}^{+}$ & $\mathrm{Na}^{+}$ & $\mathrm{PO}_{4}{ }^{3}$ \\
\hline \multirow{2}{*}{$\mathrm{pH}$} & $r$ & 1.00 & 1.00 & 0.58 & 0.59 & 0.80 & 0.89 & 0.91 & 0.86 & 0.67 & 0.92 & 0.90 \\
\hline & $P$ & & 0.036 & 0.610 & 0.594 & 0.411 & 0.306 & 0.272 & 0.336 & 0.537 & 0.253 & 0.291 \\
\hline \multirow[t]{2}{*}{ EC } & $r$ & & 1.00 & 0.53 & 0.64 & 0.83 & 0.86 & 0.89 & 0.89 & 0.71 & 0.94 & 0.92 \\
\hline & $P$ & & & 0.646 & 0.559 & 0.375 & 0.342 & 0.308 & 0.300 & 0.501 & 0.217 & 0.255 \\
\hline \multirow{2}{*}{$\mathrm{CO}_{3}$} & $r$ & & & 1.00 & -0.32 & -0.03 & 0.89 & 0.86 & 0.08 & -0.23 & 0.21 & 0.16 \\
\hline & $P$ & & & & 0.796 & 0.979 & 0.304 & 0.338 & 0.946 & 0.853 & 0.863 & 0.901 \\
\hline \multirow[t]{2}{*}{$\mathrm{HCO}_{3}$} & $r$ & & & & 1.00 & 0.96 & 0.16 & 0.21 & 0.92 & 1.00 & 0.86 & 0.89 \\
\hline & $P$ & & & & & 0.183 & 0.901 & 0.866 & 0.258 & 0.058 & 0.341 & 0.304 \\
\hline \multirow[t]{2}{*}{$\mathrm{Cl}^{-}$} & $r$ & & & & & 1.00 & 0.43 & 0.48 & 0.99 & 0.98 & 0.97 & 0.98 \\
\hline & $P$ & & & & & & 0.717 & 0.683 & 0.075 & 0.125 & 0.158 & 0.121 \\
\hline \multirow{2}{*}{$\mathrm{SO}_{4}^{2-}$} & $r$ & & & & & & 1.00 & 1.00 & 0.53 & 0.24 & 0.64 & 0.59 \\
\hline & $P$ & & & & & & & 0.034 & 0.642 & 0.843 & 0.559 & 0.597 \\
\hline \multirow[t]{2}{*}{$\mathrm{Ca}^{2+}$} & $r$ & & & & & & & 1.00 & 0.58 & 0.30 & 0.68 & 0.63 \\
\hline & $P$ & & & & & & & & 0.608 & 0.809 & 0.525 & 0.563 \\
\hline \multirow[t]{2}{*}{$\mathrm{Mg}^{2+}$} & $r$ & & & & & & & & 1.00 & 0.95 & 0.99 & 1.00 \\
\hline & $P$ & & & & & & & & & 0.201 & 0.083 & 0.045 \\
\hline \multirow[t]{2}{*}{$\mathrm{K}^{+}$} & $r$ & & & & & & & & & 1.00 & 0.90 & 0.93 \\
\hline & $P$ & & & & & & & & & & 0.284 & 0.246 \\
\hline \multirow[t]{2}{*}{$\mathrm{Na}^{+}$} & $r$ & & & & & & & & & & 1.00 & 1.00 \\
\hline & $P$ & & & & & & & & & & & 0.038 \\
\hline $\mathrm{PO}_{4}^{3-}$ & $r$ & & & & & & & & & & & 1.00 \\
\hline
\end{tabular}

$E C$ : electric conductance, $\mathrm{Cl}$ : chloride, $\mathrm{SO}_{4}$ : sulfate, $\mathrm{Na}$ : sodium, $\mathrm{K}$ : potassium, $\mathrm{Mg}$ : magnesium, $\mathrm{Ca}$ : calcium. $r$ Pearson correlation coefficient (bold); $p$, significance was set at $p<0.05$. 
Table 3: Heavy metals concentration in surface water samples collected in winter 2019, Egypt.

\begin{tabular}{|c|c|c|c|c|}
\hline \multirow[t]{2}{*}{ Heavy metals } & \multicolumn{3}{|l|}{ Sites } & \multirow{2}{*}{$\begin{array}{l}\text { Acceptable/ } \\
\text { Permissible } \\
\text { limit }^{\mathrm{a}}\end{array}$} \\
\hline & $\begin{array}{l}\text { Mariotteya stream } \\
\text { (Giza) }\end{array}$ & $\begin{array}{l}\text { Lake Qarun } \\
\text { (Fayoum) }\end{array}$ & $\begin{array}{l}\text { Mediterranean Coast } \\
\text { (Alexandria) }\end{array}$ & \\
\hline Zinc $(\mathrm{Zn})$ & ND & ND & 0.06 & $2-5 \mathrm{mg} / \mathrm{L}$ \\
\hline Copper $(\mathrm{Cu})$ & $\mathrm{ND}$ & 0.03 & ND & $1 \mathrm{mg} / \mathrm{L}$ \\
\hline Cadmium (Cd) & ND & $0.04^{b}$ & $0.04^{\mathrm{b}}$ & $0.01 \mathrm{mg} / \mathrm{L}$ \\
\hline Lead $(\mathrm{Pb})$ & ND & ND & $0.11^{\mathrm{b}}$ & $0.05 \mathrm{mg} / \mathrm{L}$ \\
\hline
\end{tabular}

ND not detected; ${ }^{a}$ According to Egyptian Chemical Standards (ECS, 1994); ${ }^{b}$ Exceeded the permissible limit; $\mathrm{Cu}, \mathrm{Cd}$, and $\mathrm{Pb}$ have comparable US Environmental Protection Agency (US-UPA, 2000) levels of 1, 0.01, and $0.005 \mathrm{mg} / \mathrm{L}$, respectively.

Table 4: Bacterial load of surface water samples collected in winter 2019, Egypt.

\begin{tabular}{lllll} 
Bacterial isolates & Unit & \multicolumn{2}{c}{ Sites } \\
Total coliform & $\mathrm{MPN} / 100 \mathrm{~mL}$ & $\begin{array}{l}\text { Mariotteya stream } \\
\text { (Giza) }\end{array}$ & $\begin{array}{l}\text { Lake Qarun } \\
\text { (Fayoum) }\end{array}$ & $\begin{array}{l}\text { Mediterranean Coast } \\
\text { (Alexandria) }\end{array}$ \\
\hline E. coli & 0.00 & 12 & 0.00 \\
\hline Total colony count & $\log _{10} \mathrm{CFU} / 100 \mathrm{~mL}$ & 0.00 & 2.95 & 0.00 \\
\hline Vibrio spp. & $\log _{10} \mathrm{CFU} / \mathrm{mL}$ & 7.08 & 6.95 & 7.51 \\
\hline Aeromonas spp. & $\log _{10} \mathrm{CFU} / \mathrm{mL}$ & 0.00 & 0.00 & 2.48 \\
\hline Pseudomonas spp. & $\log _{10} \mathrm{CFU} / \mathrm{mL}$ & 2.70 & 0.00 & 0.00 \\
\hline Staphylococcus $\mathrm{spp}$. & $\log _{10} \mathrm{CFU} / \mathrm{mL}$ & 2.04 & 3.18 & 0.00 \\
\end{tabular}

\section{DisSOLVED HEAVY METALS}

Table 3 shows that $\mathrm{Zn}, \mathrm{Cu}, \mathrm{Cd}$, and $\mathrm{Pb}$ were detected in different concentrations in waters samples collected from Alexandria Mediterranean Coast and Lake Qarun. The highest mean concentration was recorded for cadmium that exceeded the permissible limit. Moreover, none of the examined heavy metals was detected in the Mariotteya stream.

\section{Microbial CHARACTERISTICS OF EXAMINED WATER}

In the aspects of microbial water analysis (Table 4), the current study found the isolation of coliforms and E. coli only from Lake Qarun. Of all the water samples, the highest concentration of TBC was at the Mediterranean Coast (7.51 $\log _{10}$ CFU/100 mL). Also, Vibrio spp. was isolated only from the same place $\left(2.48 \log _{10} \mathrm{CFU} / \mathrm{mL}\right)$. While Aeromonas species were isolated only from the Mariotteya stream $\left(2.70 \log _{10} \mathrm{CFU} / \mathrm{mL}\right)$, Pseudomonas spp. was found in the Mariotteya water sample and Lake Qarun (2.04 and $3.18 \log _{10} \mathrm{CFU} / \mathrm{mL}$, respectively). Staphylococcus spp. was the highest in the Mariotteya stream (2.00 $\log _{10}$ CFU/ $\mathrm{mL}$ ).

\section{BACTERIOLOGICAL IDENTIFICATION OF FISH} PATHOGENS

The occurrence of natural infection rates among moribund and freshly dead marine fishes and crustaceans is shown in Table 6. Aeromonas spp. was the most prevalent bacteria with a total prevalence of $36.2 \%$. Vibrio spp. was isolated with a prevalence of $31.4 \%$ followed by Pseudomonas spp. (16.2\%) and Staphylococcus spp. (6.7\%) with the lowest prevalence.

\section{DISCUSSION}

The aquatic environment is subjected to a variety of chemicals that have negative health effects on habituated fish and pose a threat to their survival (Mackenzie et al., 1995). Domestic wastewater pollution, especially sewage pollution, is the most common in surface water recently. This pollution degrades water quality and has been identified as a precursor to fish contamination with pathogens that have public health hazards via infecting both consumers and handlers (Omer et al., 2004).

Physicochemical water examination revealed that $\mathrm{pH}$, conductivity, total suspended and dissolved solids, total alkalinity, sulfate, and phosphate were all found to affect the aquatic environment and were all increased as a result of anthropogenic factors (E1-Nemaki et al., 2008; ElAmier et al.,2015).

The results of the current study (Table 1 ) showed that the $\mathrm{pH}$ value ranged from 7.36 to 7.87 , and pond water with a $\mathrm{pH}$ of 6-9 was suitable for increased fish production (Bhatnagar and Devi, 2013). In addition, Al-Afify et al. (2019) found $\mathrm{pH}$ values within allowable limits (range, 7.29-8.84) in their study, with the highest value in 
autumn and the lowest value in winter, which was close to the findings of the current study. The $\mathrm{pH}$ value varies depending on the number of sewage emissions and the algae photosynthesis. Furthermore, lower $\mathrm{pH}$ values are linked to lower oxygen concentrations as a result of high levels of organic contaminants and brackish water drainage (Abdel-Halim and Aly-Eldeen, 2016). The same conclusion was reached by Ibrahim and Ramzy (2013), who found that the water lakes must be slightly alkaline, with an average $\mathrm{pH}$ of $8.10 \pm 0.32$.

The EC distribution among sample sites revealed spatial variation, with some sites having lower EC than others. A low EC value in the Mariotteya stream was observed (2.11 $\mathrm{ds} / \mathrm{m}$ ), which may be due to dissolved salts adsorption on the surface of suspended particles caused by flooding. Moreover, EC and salinity reflect the dilution rate of seawater by land water discharges, revealing the degree of pollution in the aquatic environment (Zyadah et al., 2004). According to Al-Afify et al. (2019), the EC of Lake Qarun water ranged from 11.20 to $53.60 \mathrm{mS} / \mathrm{cm}$, with a mean value of $43.60 \mathrm{mS} / \mathrm{cm}$. The lowest $\mathrm{EC}$ value was found at site 1 next to the El-Batts drain. However, lower values were found during the winter, which may be due to the direct effect of drainage water dilution, especially in areas near the drains. This corresponds to Authman and Abbas (2007).

The presence of cations (e.g., sodium, calcium, and magnesium), as well as anions (e.g., chloride, phosphate, and nitrate), is one of the causes of salinity (Rani et al., 2012). It comprises the total suspended solids, and water turbidity is affected by total suspended solids (Mahananda et al., 2010).

The Mariotteya values obtained in this study are relatively low, which is good for maximum fish productivity. The Mediterranean Shore, Alexandria, had the highest concentration of $\mathrm{Cl}^{-}(832.00 \mathrm{mg} / \mathrm{L})$. These findings corroborate those of Ali and Fishar (2005) and Authman and Abbas (2007). While the lowest value of $15.00 \mathrm{mg} / \mathrm{L}$ was found in El Mariotteya, a similar result was found in the Nile River in Lake Nasser (Rashed and Younis, 2012). Mariotteya $\mathrm{SO}_{4}^{2-}$ value was $20.48 \mathrm{~m} \mathrm{~g} / \mathrm{L}$, while marine water ranged from 132.09 to $263.31 \mathrm{mg} / \mathrm{L}$. Overall, the distribution of major anions $\left(\mathrm{Cl}^{-}\right.$and $\left.\mathrm{SO}_{4}{ }^{2-}\right)$ in lake water can be primarily regulated by the evaporation rate (AbdelSatar et al., 2010). The most common anion pattern was $\mathrm{Cl}^{-}, \mathrm{SO}_{4}{ }^{2-}, \mathrm{HCO}_{3-}$, and $\mathrm{CO}_{3}{ }^{-2}$. These findings are consistent with those stated by Abdel-Satar et al. (2010) and Abou El-Gheit et al., (2012). Major cations ( $\mathrm{Na}^{+}, \mathrm{K}+$, $\mathrm{Ca}^{2+}$, and $\mathrm{Mg}^{2+}$ ) concentrations in marine water ranged from 534.99 to $763.91,11.65$ to $38.18,20.00$ to 33.33 , and 90.33 to $153.00 \mathrm{mg} / \mathrm{L}$, respectively, while Mariotteya was $27.11,0.44,6.33$, and $6.00 \mathrm{mg} / \mathrm{L}$, respectively. The dominant cation pattern was $\mathrm{Na}^{+}>\mathrm{Mg}^{2+}>\mathrm{Ca}^{2+}$. The high amount of agricultural runoff and domestic sewage inflow from adjacent cultivated land and neighboring villages to the drains could be explained by the overall 'concentration levels of phosphates (Sayed and Abdel-Satar, 2009). As phosphorus builds up in a lake, it can indefinitely cycle through the water column, promoting algal blooms (Edwards and Withers, 2008). The concentrations of $\mathrm{PO}_{4}^{-3}$ were found to be between 2.19 and $2.74 \mathrm{mg} / \mathrm{L}$. This may be because most fish farmers feed their fish with artificial feeds.

The correlation coefficient $(r)$ between different chemical parameters in the studied water samples is shown in Table 2 , which shows a strong correlation between them.

Heavy metals are common trace elements in marine ecosystems, but their levels have risen because of anthropogenic effects (i.e., industrial, agricultural, and mining activities) (Kalay and Canli, 2000). The most common heavy metals that have a direct effect on marine animals and their natural habitats are mercury, cadmium, and lead (Ramamoorthy and Ballantyne, 1984; Ullrich et al., 2001).

The results of the current study (Table 3) indicated the heavy metal concentration in the studied sample. According to US-UPA and ESC standards, water samples from Lake Qarun were contaminated with $\mathrm{Cd}$ beyond the acceptable level, whereas water samples from Alexandria province were polluted with $\mathrm{Cd}$ and $\mathrm{Pb}$. In addition, all 'sites' $\mathrm{Zn}$ and $\mathrm{Cu}$ levels were within acceptable limits. The findings of the current study supported the findings of other studies (Sawere and Oghenekowhoyan, 2019). However, lead was found to be the most abundant heavy metal in the water sample (range, $0.18-0.23 \mathrm{mg} / \mathrm{L}$ ). Metal pollution poses environmental issues, such as possible effects on the food chain, long-term persistence, and biomagnification in the food chain (Karadede-Akin and Ünlü, 2007; Papagiannis et al.,2004), which may be dangerous to humans. Cadmium and lead are two of the most dangerous toxins in the food chain. Cadmium causes Itai-Itai disease, which is a debilitating lung disease. Lead adversely affects the blood, various tissues, and the nervous system (Malhat, 2011).

In aspects of microbial water analysis as shown in Table 4, biotyping of certain bacterial isolates revealed the existence of bacteria that pose a significant risk to human health, including E. coli, Pseudomonas fuorescens, and Staphylococcus aureus. Many studies have discussed the health risks of bacterial isolates as dangerous microorganisms that affect humans and cause a variety of diseases (Kenzaka et al., 2013). the findings of the current study showed the 
isolation of coliforms and E. coli at Lake Qarun, which can be used as bioindicators of fecal contamination (Rajasekaran, 2008). Lake Qarun is the largest reservoir of agricultural and sewage drainage in Fayoum Province, as well as the drainage from fish farms built around the lake, (Mansour and Sidky, 2003). E. coli is the best biological water predictor for public health safety (Edberg et al., 2000). Microbial water analysis at Mariotteya drain showed the isolation of Pseudomonas, Aeromonas, and S. aureus. These results follow Rokibul et al. (2013) who isolate Staphylococcus $\left(30 \times 10^{3} \mathrm{CFU} / \mathrm{mL}\right)$ and Aeromonas $\left(50 \times 10^{3} \mathrm{CFU} / \mathrm{mL}\right)$ by count in the summer, and the lowest value throughout the winter $\left(0.25 \times 10^{3} \mathrm{CFU} / \mathrm{mL}\right)$. No coliform count $(0.0 \mathrm{CFU} / \mathrm{mL})$ was noted in the winter. Furthermore, at Alexandria, 'Egypt's Mediterranean Sea coast has a climate close to that of 'Europe's Eastern and Southern coasts. A study in Turkey found Vibrio in $66.0 \%$ of the samples, which was nearly identical to other studies (Colakoglu et al., 2006). The total prevalence of bacterial infections in naturally infected marine fishes (40.83\%) may appear to be lower than those recorded by some authors for freshwater fishes, such as Soliman (1999) who found that TBC prevalence was $65.0 \%$. This variation may be due to the negative impact of seawater salinity on bacterial pathogen viability. The isolated bacteria were reported during the sampling period (November 2019-January 2020) in the current sample, and this finding could be attributed to the 'areas' continued chemical and sewage contamination. More studies are needed, however, to show that this form of pollution has a seasonal impact across the year. Organic water contamination, accompanied by a decrease in dissolved oxygen content, provides a favorable environment for bacterial development. A well-established connection was noted between organic contamination of surface water and disease outbreaks. Thus, this disease may act as a warning sign of water contamination or poor water quality. The results of the current study illustrated the correlation between water chemical parameters and bacterial load (Table 5).

The negative shift in water quality parameters occasionally influences and enhances pathogenic bacterial replication and increases the susceptibility of fish to bacterial infection (E1-Bouhy et al., 2016; Abdel-Moneam et al., 2021).

Table 5: Correlation matrix of the examined water samples (between chemical parameter and microbiological load).

\begin{tabular}{|c|c|c|c|c|c|c|c|c|}
\hline & & $\begin{array}{l}\text { Total coli- } \\
\text { form }\end{array}$ & E.coli & $\begin{array}{l}\text { Total colony } \\
\text { count }\end{array}$ & Vibrio spp. & Aeromonas spp. & $\begin{array}{l}\text { Pseudomonas } \\
\text { spp. }\end{array}$ & $\begin{array}{l}\text { Staphylococcus } \\
\text { spp. }\end{array}$ \\
\hline \multirow[t]{2}{*}{$\mathrm{pH}$} & $r$ & 0.58 & 0.58 & 0.21 & 0.42 & -1.00 & -0.07 & -0.46 \\
\hline & $P$ & 0.610 & 0.610 & 0.866 & 0.723 & 0.057 & 0.954 & 0.695 \\
\hline \multirow[t]{2}{*}{$\mathrm{EC}$} & $r$ & 0.53 & 0.53 & 0.26 & 0.47 & -1.00 & -0.13 & -0.51 \\
\hline & $P$ & 0.646 & 0.646 & 0.830 & 0.688 & 0.021 & 0.918 & 0.659 \\
\hline \multirow{2}{*}{$\mathrm{CO}_{3}$} & $r$ & 1.00 & 1.00 & -0.68 & -0.50 & -0.50 & 0.77 & 0.46 \\
\hline & $P$ & 0.000 & 0.000 & 0.524 & 0.667 & 0.667 & 0.436 & 0.695 \\
\hline \multirow{2}{*}{$\mathrm{HCO}_{3}$} & $r$ & -0.32 & -0.32 & 0.91 & 0.98 & -0.66 & -0.84 & -0.99 \\
\hline & $P$ & 0.796 & 0.796 & 0.271 & 0.129 & 0.538 & 0.359 & 0.10 \\
\hline \multirow[t]{2}{*}{$\mathrm{Cl}^{-}$} & $r$ & -0.03 & -0.03 & 0.76 & 0.88 & -0.85 & -0.66 & -0.90 \\
\hline & $P$ & 0.979 & 0.979 & 0.455 & 0.312 & 0.354 & 0.542 & 0.284 \\
\hline \multirow[t]{2}{*}{$\mathrm{SO}_{4}^{2-}$} & $r$ & 0.89 & 0.89 & -0.27 & -0.05 & -0.84 & 0.40 & 0.00 \\
\hline & $P$ & 0.304 & 0.304 & 0.828 & 0.970 & 0.363 & 0.740 & 0.999 \\
\hline \multirow[t]{2}{*}{$\mathrm{Ca}^{2+}$} & $r$ & 0.86 & 0.86 & -0.21 & 0.01 & -0.87 & 0.35 & -0.05 \\
\hline & $P$ & 0.338 & 0.338 & 0.862 & 0.995 & 0.329 & 0.774 & 0.967 \\
\hline \multirow[t]{2}{*}{$\mathrm{Mg}^{2+}$} & $r$ & 0.08 & 0.08 & 0.67 & 0.82 & -0.91 & -0.57 & -0.85 \\
\hline & $P$ & 0.946 & 0.946 & 0.530 & 0.387 & 0.279 & 0.618 & 0.359 \\
\hline \multirow[t]{2}{*}{$\mathrm{K}^{+}$} & $r$ & -0.23 & -0.23 & 0.87 & 0.96 & -0.73 & -0.79 & -0.97 \\
\hline & $P$ & 0.853 & 0.853 & 0.329 & 0.187 & 0.480 & 0.417 & 0.159 \\
\hline \multirow[t]{2}{*}{$\mathrm{Na}^{+}$} & $r$ & 0.21 & 0.21 & 0.57 & 0.74 & -0.95 & -0.45 & -0.77 \\
\hline & $P$ & 0.863 & 0.863 & 0.613 & 0.470 & 0.196 & 0.701 & 0.442 \\
\hline \multirow[t]{2}{*}{$\mathrm{PO}_{4}^{3-}$} & $r$ & 0.16 & 0.16 & 0.62 & 0.78 & -0.93 & -0.51 & -0.80 \\
\hline & $P$ & 0.901 & 0.901 & 0.575 & 0.433 & 0.234 & 0.663 & 0.405 \\
\hline
\end{tabular}

$E C$ : electric conductance, $C l$ : chloride, $S O$ : sulfate, $N a$ : sodium, $K$ : potassium, $M g$ : magnesium, $C a$ : calcium; $r$ Pearson correlation coefficient; $p$, significance was set at $p<0.05$. 
Table 6: Rate of bacterial isolation in relation to the number of collected fish Obtained from different localities from Egypt winter, 2019.

\begin{tabular}{|c|c|c|c|c|c|c|c|c|}
\hline & $\begin{array}{l}\text { Mariotteya } \\
\text { stream } \\
\text { (Giza) }\end{array}$ & $\begin{array}{l}\text { Lake Qarun } \\
\text { (Fayoum) } \\
(\mathrm{N}=85)\end{array}$ & & & & $\begin{array}{l}\text { Mediterrane- } \\
\text { an coast } \\
\text { (Alexandria) }\end{array}$ & $\begin{array}{l}\text { Total }(\mathrm{N}= \\
105)\end{array}$ & $\begin{array}{l}P \text { value } \\
(F E T)\end{array}$ \\
\hline & $\begin{array}{l}\text { Nile Tilapia } \\
(n=5)(\%)\end{array}$ & $\begin{array}{l}\text { Nile Tilapia } \\
(n=30)(\%)\end{array}$ & $\begin{array}{l}\text { Tilapia zillii } \\
(\mathrm{n}=5)(\%)\end{array}$ & $\begin{array}{l}\text { Artemia shrimp } \\
(n=50)(\%)\end{array}$ & $\begin{array}{l}\text { Overall }(\mathrm{N}= \\
85)(\%)\end{array}$ & $\begin{array}{l}\text { Large shrimp } \\
(n=15)(\%)\end{array}$ & & \\
\hline Vibrio spp. & $0 / 5(0.0)$ & $5 / 30(16.6)$ & $2 / 5(40.0)$ & $20 / 50(40.0)$ & $27 / 85(31.8)$ & $6 / 15(40.0)$ & $33 / 105$ (31.4) & 0.285 \\
\hline Aeromonas spp. & $4 / 5(80.0)$ & $20 / 30(66.6)$ & $2 / 5(40.0)$ & $10 / 50(20.0)$ & $32 / 85(37.6)$ & $2 / 15(10.0)$ & $38 / 105(36.2)$ & $0.020^{*}$ \\
\hline Pseudomonas spp. & $1 / 5(20.0)$ & $5 / 30(16.6)$ & $1 / 5(20.0)$ & $10 / 50(20.0)$ & $16 / 85(18.8)$ & $0 / 15(0.0)$ & $17 / 105(16.2)$ & 0.142 \\
\hline Staphylococcus spp. & $0 / 5(0.0)$ & $5 / 30(16.6)$ & $1 / 5(20.0)$ & $0 / 50(0.0)$ & $6 / 85(7.1)$ & $1 / 15(6.6)$ & 7/105 (6.7) & 1.000 \\
\hline$\chi^{2}(3)$ & $F E T$ & 27.23 & $F E T$ & 25.00 & 26.24 & $F E T$ & 33.45 & \\
\hline$P$ value & $0.020^{*}$ & $<0.0001^{*}$ & 1.000 & $<0.0001^{*}$ & $<0.0001^{*}$ & $0.020^{*}$ & $<0.0001^{*}$ & \\
\hline
\end{tabular}

$\chi^{2}$ : Chi-square test, FET: Fisher's exact test. ${ }^{*} P<0.05$, significant.

Concerning the results of bacterial isolates retrieved from fish samples (Table 6), the Gram-negative bacteria were more isolated than Gram-positive bacteria. Fish and shrimp samples collected from Lake Qarun and the Mediterranean Coast (Alexandria) were contaminated with all investigated microorganisms, while fish collected from the Mariotteya stream was only contaminated with Pseudomonas spp. and Aeromonas spp. The findings of the current study showed that shrimp and Nile Tilapia were the most infected Aquatic species, followed by T. zillii. This may be related to suboptimal water conditions that lead to physiological stress on reared fish and shrimps, which compromised the ability of shrimp to resist disease that consequently promotes infection (Millard et al., 2020). Moreover, the shrimp habitat as a benthic aquatic crustacean makes them more susceptible to concentrated levels of various water pollutants.

Concerning the percentages of the prevalence of the isolated bacterial groups, the results of the current study revealed that Aeromonas were the most prevalent species of all bacterial groups (Aboyadak et al., 2015; AbdelMoneam et al., 2021) accounting for $80 \%$ and $37.6 \%$ in Mariotteya stream and Lake Qarun, respectively. This may be related to the ubiquitous nature of Aeromonas spp. in the fish gut flora and aquatic environments. Moreover, the high prevalence of Aeromonas spp. during winter was similar to that reported by Moustafa et al. (2010) and El-Barbary and Hal (2016) who confirm the isolation of Aeromonas bacteria in the late winter.

Vibriosis is one of the most common bacterial diseases affecting various marine fish species and crustaceans (Sarjito et al., 2009). In the current study, Vibrio species were isolated from the Mediterranean coasts water (40\%) and Lake Qarun (31.8\%), which is nearly similar to that reported by Abdelaziz et al. (2017) and Elgohary et al. (2020) in different marine localities.
Vibrio bacterial infection may be related to the high salinity of the Mediterranean coasts water and Lake Qarun that acts as a closed saline basin that receives agricultural, sewage, and fish farms drainage wastewater of Fayoum Province (Authman and Abbas, 2007; Abdelaziz et al., 2017). The high salinity levels accompanied by decrease in dissolved oxygen content act as a predisposing stress factor that may suppress fish immunity and lead to concurrent bacterial infection.

The prevalence of infection with Pseudomonas spp. was $20 \%$ and $18.8 \%$ in the Mariotteya stream and Lake Qarun, respectively. Nearly similar to Hussain (2002), El-Barbary and $\mathrm{Hal}$ (2016) and Elgohary et al. (2020) reported an increase in infection percentage with Pseudomonas species in the cold months of winter, which may be attributed to the affinity of Pseudomonas for propagation and widespreading infection at low temperatures (El-Moghazy, 2004; Golomazou et al., 2006).

Staphylococcus spp. recorded the lowest infection percentage among the examined fishes in Lake Qarun and Alexandria with a total prevalence of $6.7 \%$. Similarly, Zorrilla et al. (2003) and Moustafa et al. (2010) reported a low percentage of isolation of Gram-positive bacteria in different fish species in winter. Opposing Varvarigos (2001) who declared that the most common Staphylococcus spp. causing septicemia were isolated at high seawater temperature in late spring and early summer. The variation in bacterial prevalence percentage is mainly contributed to the difference in examined fish species, water quality parameters, variable enviromental conditions and different localities.

\section{CONCLUSIONS AND RECOMMENDATIONS}

Monitoring the water quality in a fish facility's aquariums 
is critical for maintaining a safe fish supply. Moreover, preserving water quality is also important because contamination with pathogenic microorganisms can cause serious illness or even death in cultured water organisms.

\section{NOVELTY STATEMENT}

The current study assessed the relationship between physicochemical qualities and the occurrence of bacteria causing fish diseases in three different types of surface water bodies in Egypt: Sea water, Lake water, and water stream.

\section{AUTHOR'S CONTRIBUTION}

H.S.K.: analysis of water samples chemically and bacteriologically, D.A.A: identification and isolation of fish bacterial diseases, E.I.: statistical analysis for data, H.S.K, E.I. and D.A.A. writing and final editing, M.M.F and M.S.G. sample collecting and participate in the practical work, H.S.K and E.I. work design, M.M.Z. supervision, all authors have read and agreed to the published version of the manuscript.

\section{CONFLICT OF INTEREST}

The authors have declared no conflict of interest.

\section{REFERENCES}

-Abd El-Hady BA (2007). Compare the effect of polluted and river Nile irrigation water on. Res. J. Agric. Biol. Sci., 3(4): 287-294.

-Abdallah MAM, Elmagd MFA (2013). Persistent organochlorine pollutants and metals residues in sediment and freshwater fish species cultured in a shallow lagoon, Egypt. Environ. Technol., 34(16): 2389-2399. https://doi.or $\mathrm{g} / 10.1080 / 09593330.2013 .770561$

-Abdelaziz M, Ibrahem MD, Ibrahim MA, Abu-Elala NM, Abdel-moneam DA (2017). Monitoring of different vibrio species affecting marine fishes in Lake Qarun and Gulf of Suez. Phenotypic and molecular characterization. Egypt. J. Aquat. Res., 43: 141-146. https://doi.org/10.1016/j. ejar.2017.06.002

-Abdel-Halim AM, Aly-Eldeen MA (2016). Characteristics of Mediterranean Sea water in vicinity of Sidikerir Region, west of Alexandria, Egypt. Egypt. J. Aquat. Res., 42(2): 133140. https://doi.org/10.1016/j.ejar.2016.05.002

-Abdel-moneam DA, Ibrahim RA, Nashaat M, Shaalan $M$ (2021). Multifactorial causes of mass mortality in Oreochromis niloticus in Kafr El-Sheikh, Egypt. 6, Bull. Eur. Ass. Fish Pathol., 41(1): 2021.

-Abdel-Satar AM, Goher ME, Sayed MFF (2010). Recent environmental changes in water and sediment quality of Lake Qarun Qarun, Egypt. J. Fish. Aquat. Sci., 5: 56-69. https://doi.org/10.3923/jfas.2010.56.69

-Abou El-Gheit EN, Abdo MH, Mahmoud SA (2012). Impacts of blooming phenomenon on water quality and fishes in Quarun Lake, Egypt. Int. J. Environ. Sci. Eng., 3: 11-23.
- Aboyadak IM, Nadia GMA, Goda AA, Aboelgalagel WH, Alnokrashy A (2015). Molecular detection of Aeromonas bydrophila as the main cause of outbreak in tilapia farms in Egypt. J. Aquacult. Mar. Biol., 2(5): 00045. https://doi. org/10.15406/jamb.2015.02.00045

-Al-Afify ADG, Tahoun UM, Abdo MH (2019). Water quality index and microbial assessment of Lake Qarun Qarun, El-Batts and El-Wadi Drains, Fayoum Province, Egypt. Egypt. J. Aquat. Biol. Fish., 23(1): 341-357. https://doi. org/10.21608/ejabf.2019.28270

-Al-Harbi AH, Uddin N (2005). Bacterial diversity of tilapia (Oreochromis niloticus) cultured in brackish water in Saudi Arabia. Aquaculture, 250(3-4): 566-572. https://doi. org/10.1016/j.aquaculture.2005.01.026

-Ali A, ElSayed M, Radwan R, Hefny R (2020). An economic study of the fish production system in Egypt. SINAI J. Appl. Sci., 9(1): 105-116.

-Ali MHH, Fishar MRA (2005). Accumulation of trace metals in some benthic invertebrate and fish species relevant to their concentration in water and sediment of Lake Qarun Qarun, Egypt. Egypt. J. Aquat. Res., 31(1): 289-301.

-APHA, American Public Health Association (2012). Standard methods for the examination of water and wastewater $\left(20^{\text {th }}\right.$ ed.) Washington.

-APHA, American Public Health Association (1970). Recommended methods for the examination of seawater and shellfish, $4^{\text {th }}$ edition, Amer. Pub. Health Assoc., New York.

-APHA, American Public Health Association (1998). Standard Methods for the Examination of Water and Wastewater. The 20thEd. APHA, Inc. New York.

-APHA, American Public Health Association (2005). Standard Methods for the Examination of Water and Wastewater, Amer. Publ. Heal. Assoc., Amer. Water Works Assoc. and Water Poll. Contr. Fed., Washington, DC

-Authman MMN, Abbas H (2007). Accumulation and distribution of copper and zinc in both water and some vital tissues of two fish species (Tilapia and Mugil cephalus) of Lake Qarun, Fayoum Province, Egypt. Pakistan J. Biol. Sci., 10(13): 2105-2122. https://doi.org/10.3923/ pjbs.2007.2106.2122

-Beveridge TJ (2001). Use of the Gram stain in microbiology. Biotech. Histochem., 76(3): 111-118. https://doi. org/10.1080/714028139

-Bhatnagar, A. and Devi, P (2013). Water quality guidelines for the management of pond fish culture. Int. J. Environ. Sci., 3(6): $1980-1997$.

- CCME, Canadian Council of Ministers of the Environment (2007). For the protection of aquatic life. In: Canadian environmental quality guidelines, 1999. Canadia in Council of Ministers of the Environment, 1999, Winnipeg.

- Colakoglu FA, Sarmasik A, Koseoglu B (2006). Occurrence of Vibrio spp. and Aeromonas spp. in shellfish harvested off Dardanelles Dardanelles's cost of Turkey. Food Contr., 17(8): 648-652. https://doi.org/10.1016/j.foodcont.2005.04.014

- Dhanakumar S, Solaraj G, Mohanraj R (2015). Heavy metal partitioning in sediments and bioaccumulation in commercial fish species of three major reservoirs of river Cauvery delta region, India. Ecotoxicol. Environ. Saf., 113: 145-151. https://doi.org/10.1016/j.ecoenv.2014.11.032

-Diersing N (2009). Water quality: Frequently asked questions. Florida brooks national marine sanctuary, key west, FL Diersing, N. (2009). Water quality: Frequently asked 
questions PDA.

- ECS (1994). Egyptian chemical standards. Protection of the Nile River and water stream from pollution, Ministry of Irrigation, Cairo, Egypt, Law No 4.

-Edberg SCL, Rice EW, Karlin RJ, Allen MJ (2000). Escherichia coli: The best biological drinking water indicator for public health protection. J. Appl. Microbiol., 88(S1): 106S-116S. https://doi.org/10.1111/j.1365-2672.2000.tb05338.x

-Edwards AC, Withers PJA (2008). Transport and delivery of suspended solids, nitrogen and phosphorus from various souries to fresh water in the UK. J. Hydrol., 350: 144-153. https://doi.org/10.1016/j.jhydrol.2007.10.053

-Eissa IAM (2002). Text book textbook of parasitic fish diseases in Egypt. Dar El-Nahdda El-Arabia, Cairo, Egypt.

-El-Amier YA, Zahran MAEK, Al-Mamory SH (2015). Assessment the physico-chemical characteristics of water and sediment in Rosetta Branch, Egypt. J. Water Resour. Prot., 7(13); 1075. https://doi.org/10.4236/jwarp.2015.713088

-El-Barbary MI, Hal AM (2016). Isolation and molecular characterization of some bacterial pathogens in El-Serw fish farm, Egypt. Egypt. J. Aquat. Biol. Fish., 20(4): 115-127. https://doi.org/10.21608/ejabf.2016.11183

•El-Bouhy Z, El-Nobi G, El-Murr A, Abd El-Hakim S (2016). Study On vibriosis in mugil capito in El-Dakahlia and Damitta Governorates, Egypt. Abbassa Int. J. Aquat., 9(1): 2016.

- Elgohary I, Abd Elatief JI, Fadel NG, Eissa AE, Mahmoud MA (2020). Pathological, bacteriological and seasonal prevalence of Aeromonas hydrophila, vibrio vulnificus, Proteus vulgaris and Pseudomonas aeruginosa; infecting Oreochromis niloticus in some Egyptian fish farms. Egypt. J. Aquat. Biol. Fish., 24(5): 467-482. https://doi.org/10.21608/ejabf.2020.108585

-El-Moghazy DF (2004). Studies on pseudomonas septicemia in cultured Oreochromis niloticus fish. Thesis, M.V.Sc., Fish Disease Manage., Fac. Vet. Med. Suez Canal Univ.,

-El-Nemaki FA, Ali NA, Zeinhom MM, Radwan OA (2008). Impacts of different water resources on the ecological parameters and the quality of tilapia production at E1Abbassa fish farms in Egypt. $8^{\text {th }}$ Int. Symp. Tilapia Aquacult., 491: 491-512.

-Elsayed M, Essawy M, Shabana I, Abou El-Atta M, EL-Banna N (2018). Studies on bacterial pathogens in some marine fishes in EL-Mansoura, Egypt. Am. J. Agric. Biol. Sci., 13(1): 9-15.

- Falaise C, François C, Travers MA, Morga B, Haure J, Tremblay R, Mouget JL (2016). Antimicrobial compounds from eukaryotic microalgae against human pathogens and diseases in aquaculture. Mar. Drugs, 14(9): 159. https://doi. org/10.3390/md14090159

-FAO, Food and Agriculture Organization (1994). Water quality for agriculture, irrigation agriculture, irrigation and drainage. Rome, paper no. 29. In: Eds. Ayers RS, Westcot DW (eds).

- Giannoulis N, Maipa V, Konstantinou I, Albanis T, Dimoliatis I (2005). Microbiological risk assessment of Agios Georgios source supplies in Northwestern Greece based on faecal coliforms determination and sanitary inspection survey. Chemosphere, 58(9): 1269-1276. https://doi.org/10.1016/j. chemosphere.2004.09.078

- Golomazou E, Athanassopoulou F, Vagianou S, Sabatakou O, Tsantilas H, Rigos G, Kokkokiris L (2006). Diseases of white sea bream (Diplodus sargus L.) reared in experimental and commercial conditions in Greece Turk. J. Vet. Anim. Sci., 30: 389-396.
- Hussain RA (2002). Studies on some bacterial infections affecting certain marine fishes in the Arabian Gulf of Kingodom of Saudi Arabia. Thesis M.V.Sc., Fac. Vet. Anim. Res. King Faisal Univ.,

-Ibrahim LA, Ramzy EM (2013). Water quality and its impact on Tilapia Zilli (Case study) Qarun Qarun Lake-Egypt. Int. Water Technol. J., 3(4): 170-191.

- Kalay M, Canli M (2000). Elimination of essential (Cu, Zn) and nonessential $(\mathrm{Cd}, \mathrm{Pb})$ metals from tissue of a freshwater fish Tilapia Zilli. Turk. J. Zool., 24: 429-436.

-Kaleem O, Sabi ABS (2020). Overview of aquaculture systems in Egypt and Nigeria, prospects, potentials, and constraints, Aquacult. Fish., ISSN 2468-550X. https://doi. org/10.1016/j.aaf.2020.07.017

-Karadede-Akin H, Ünlü E (2007). Heavy metal concentrations in water, sediment, fish and some benthic organisms from Tigris River, Turkey. Environ. Monit. Assess., 131(1): 323 337. https://doi.org/10.1007/s10661-006-9478-0

-Kenzaka T, Takamura N, Kumabe A, Takeda K (2013). A case of subacute infective endocarditis and blood access infection caused by Enterococcus durans. BMC Infect. Dis., 13(1): 1-4. https://doi.org/10.1186/1471-2334-13-594

-MacKenzie K, Williams HH, Williams B, McVicar AH, Siddall $\mathrm{R}$ (1995). Parasites as indicators of water quality and the potential use of helminth transmission in marine pollution studies. Adv. Parasitol., 35: 85-144. https://doi.org/10.1016/ S0065-308X(08)60070-6

-Mahananda MR, Mohanty BP, Behera NR (2010). Physicochemical analysis of surface and ground water of Bargarh District, Orissa, India. Int. J. Res. Rev. Appl. Sci., 2(3): 284295.

-Malhat F (2011). Distribution of heavy metal residues in fish from the River Nile Tributaries in Egypt. Bull. Environ. Contam. Toxicol., 87: 163-165. https://doi.org/10.1007/ s00128-011-0314-z

-Mahmoud MA, Attia MM, Abdelsalam M, Abdel-Moneam DA, Ewiss MAZ (2021). Ergasilus extensus and bacterial co-infection in flathead gray mullet, Mugil cephalus (Linnaeus, 1758) are associated with pathological changes and immunological gene expression alterations. https://doi. org/10.1111/are.15476

- Mansour SA, Sidky MM (2003). Ecotoxicological studies 6. The first comparative study between Lake Qarun Qarun and Wadi El-Rayan wetland (Egypt), with respect to contamination of their major components. Fd. Chem., 82(2): 181-189. https://doi.org/10.1016/S0308-8146(02)00451-X

- Millard RS, Ellis RP, Bateman KS, Bickley LK, Tyler CR, Aerle RV, Santos EM (2020). How do abiotic environmental conditions influence shrimp susceptibility to disease? A critical analysis focussed on white spot disease. J. Invert. Pathol., https://doi.org/10.1016/j.jip.2020.107369

- Moustafa M, Mohamed LA, Mahmoud MA, Soliman WS, El-Gendy MY (2010). Bacterial infections affecting marine fishes in Egypt. J. Am. Sci., 6(11).

- Omer AAM, Ibrahim MS, El-Haddad AA, Ali MHM (2004). Environmental consequences of improper land application of sewage waste water disposal in Sohag, Egypt. Soil and ground water pollution. Sci. Conf. Dev. Environ. Arab World, pp. 23-25.

- Papagiannis I, Kagalou I, Leonardos J, Petridis D, Kalfakakou V (2004). Copper and zinc in four freshwater fish species from Lake Pamvotis (Greece). Environ. Int., 30: 357-362. https:// doi.org/10.1016/j.envint.2003.08.002 
- Rajasekaran P (2008). Enterobacteriaceae group of organisms in sewage-fed fishes. Adv. Biotech., 8: 12-14.

- Ramamoorthy S, Ballantyne EE (1984). Heavy metals in natural waters: applied monitoring and impact assessment. https:// doi.org/10.1007/978-1-4612-5210-8

- Rani CR, Reema C, Alka S, Singh PK (2012). Salt tolerance of Sorghum bicolor cultivars during germination and seedling growth. Res. J. Recent Sci., 1(3): 1-10.

- Rashed MN, Younis M (2012). Physico-Chemical and Bacterial Characteristics of Water Quality in Three Villages West of Lake Nasser, Egypt. Clean Soil, Air, Water, 40(11): 12291235. https://doi.org/10.1002/clen.201100030

- Rokibul MH, Mrityunjoy A, Eshita D, Kamal KD, Tasnia A, Muhammad AA, Kazi KF, Rashed N (2013). Microbiological study of sea fish samples collected from local marketsin Dhaka city. Int. Fd. Res. J., 20(3): 1491-1495.

- Ronald MA (2010). Hand book of microbilogical media. CRC Taylor and Francis Group Boca Raton London New York, USA.

- Saad SMM, El-Deeb AE, Tayel SI, Al-Shehri E, Ahmed NAM (2012). Effect of heavy metals pollution on histopathological alterations in muscles of Clarias gariepinus inhabiting the Rosetta branch, River Nile, Egypt. Anim. Biotechnol., pp. 79-88.

- Saeed SM, Shaker IM (2008). Assessment of heavy metals pollution in water and sediments and their effect on Oreochromis niloticus in the northern delta lakes, Egypt. Central Laboratory for Aquaculture Research, Agricultural Research Center. Limnology Department. $8^{\text {th }}$ Int. Symp. Tilapia Aquacult. 2008: 475-490.

- Sargaonkar A, Deshpande V (2003). Development of an overall index of pollution for surface water based on a general classification scheme in Indian context. Environ. Monit. Assess., 89(1): 43-67. https://doi. org/10.1023/A:1025886025137

-Sarmento A, Guilhermino L, Afonso A (2004). Mercury chloride effects on the function and cellular integrity of sea bass (Dicentrarchus labrax) head kidney macrophages. Fish Shellf. Immunol., 17(5): 489-498. https://doi.org/10.1016/j. fsi.2004.05.004

- Sawere BT, Oghenekowhoyan OC (2019). Determination of some physicochemical parameters and selected heavy metals from water collected from concrete fish ponds fishponds in Ozoro town. Int.J. Adv. Sci. Res. Eng., 5(5): 1-7. https://doi. org/10.31695/IJASRE.2019.33234

- Sarjito R, Radjasa OK, Sabdono A, Prayitno SB, Hutabarat S (2009). Phylogenetic diversity of the causative agents of vibriosis associated with groupers fish from Karimunjawa Islands, Indonesia. Curr. Res. Bacteriol., 2: 14-21. https:// doi.org/10.3923/crb.2009.14.21

- Sayed MF, Abdel-Satar AM (2009). Chemical assessment of wadi El-Rayan Lakes Egypt. Am. Eurasian J. Agric. Environ. Sci., 5: 53-62.

- Simpi B, Hiremath SM, Murthy KNS, Chandrashekarappa KN, Patel AN, Puttiah ET (2011). Analysis of water quality using physico-chemical parameters Hosahalli Tank in Shimoga District, Karnataka, India. Glob. J. Sci. Front. Res., 11(3): 31-34.

- Soliman WSE (1999). Bacteriological studies on fresh water freshwater fish. Thesis, M.V.Sc., Microbiol., Fac. Vet. Med. Cairo. Univ.

- Ullrich SM, Tanton TW, Abdrashitova SA (2001). Mercury in the aquatic environment: a review of factors affecting methylation. Crit. Rev. Environ. Sci. Technol., 31(3): 241293. https://doi.org/10.1080/20016491089226

-US-UPA, United States Environmental Protection Agency (2000). Guidance for assessing chemical contaminant data for use in fish advisories, Vol. 1. Fish1. Fish sampling and analysis $3^{\text {rd }}$ ed, office of sciencerdand Technology office of water USPA Washington, DC EPA 823-00-007, pp: 1-200.

- Varvarigos P (2001). Gram positive coccibacteria, Micrococcaceae, Streptococcaceae, causing systemic disease in intensively farmed fish. December. Varvarigose. Athens, Greece.

-Wamala SP, Mugimba KK, Mutoloki S, Evensen Ø, Mdegela R, Byarugaba DK, Sørum H (2018). Occurrence and antibiotic susceptibility of fish bacteria isolated from Oreochromis niloticus (Nile tilapia) and Clarias gariepinus (African catfish) in Uganda. Fish. Aquat. Sci., 21(1): 1-10. https:// doi.org/10.1186/s41240-017-0080-x

- Yarsan E, Yipel M (2013). The important terms of marine pollution biomarkers and biomonitoring, bioaccumulation, bioconcentration, biomagnification. J. Mol. Biomark Diagn. S., 1(2). https://doi.org/10.4172/2155-9929.S1-003

-Yaseen MS, Abdelaziz M, Abdel-Moneam DA, Abd-Elhay E, Wassif IM, fawzy M, Moustafa M (2020). Phenotypic and Genotypic characterization of the pathogenic Pseudomonas aeruginosa isolated from cultured Pangasianodon bypophthalmus in Egypt. Egypt. J. Aquat. Biol. Fish., 24(6): 453-467. https://doi.org/10.21608/ejabf.2020.117086

-Younis NA, Laban SE, Al-Mokaddem AK, Attia MM (2020). Immunological status and histopathological appraisal of farmed Oreochromis niloticus exposed to parasitic infections and heavy metal toxicity. Aquacult. Int., https:// doi.org/10.1007/s10499-020-00589-y

-Zhang Z, Lan J, Li Y, Hu M, Yu A, Zhang J, Wei S (2018). The pathogenic and antimicrobial characteristics of an emerging Streptococcus agalactiae serotype IX in Tilapia. Microbial. Pathogen., 122: 39-45. https://doi.org/10.1016/j. micpath.2018.05.053

-Zorrilla I, Arijo S, Chabrillon M, Diaz P, Martinez-Manzanares E, Balebona MC, Morinigo MA (2003). Vibrio species isolated from diseased farmed sole, Solea senegalensis (Kaup), and evaluation of the potential virulence role of their extracellular products. J. Fish Dis., 26(2): 103-108. https:// doi.org/10.1046/j.1365-2761.2003.00437.x

-Zyadah M, Ibrahim M, Madkour A (2004). Impact of environmental parameters on benthic invertebrates and zooplankton biodiversity of the Eastern region of Delta coast at Damietta, Egypt. Egypt. J. Aquat. Biol. Fish., 8(4): 37-52. https://doi.org/10.21608/ejabf.2004.1808 